\title{
Smooth lumpsucker Aptocyclus ventricosus in the northwestern Sea of Japan: distribution and some life history traits
}

\author{
Sergei F. Solomatov, Alexei M. Orlov
}

Received - 14 August 2017/Accepted - 06 December 2017. Published online: 31 March 2018; @Inland Fisheries Institute in Olsztyn, Poland Citation: Solomatov S.F., Orlov A.M. 2018 - Smooth lumpsucker Aptocyclus ventricosus in the northwestern Sea of Japan: distribution and some life history traits - Fish. Aquat. Life 26: 5-20.

\begin{abstract}
This paper is focused on horizontal, vertical, and temperature-dependent distributions, size composition of bottom and mid-water trawl catches, and biomass estimations of smooth lumpsucker Aptocyclus ventricosus (Pallas) (Cyclopteridae) within the Russian Exclusive Economic Zone (EEZ) of the northwestern Sea of Japan. This species is distributed very widely throughout the study area inhabiting both near-bottom layers and water column. It is less abundant in small bays and in the northern Tatar Strait (north to $50^{\circ} \mathrm{N}$ ). Despite wide bathymetric ( 0 to $940 \mathrm{~m}$ ) and temperature (-1.1 to $+12.2^{\circ} \mathrm{C}$ ) ranges this species occurred mainly within the
\end{abstract}

\section{S.F. Solomatov}

Sector for Integrated Resource Research in the Sea of Japan, Pacific

Research Fisheries Center, Russia

A.M. Orlov [ $\left.\Xi^{\circ}\right]$

Sector of Arctic, Russian Federal Research Institute of Fisheries and Oceanography, Russia

e-mail: orlov@vniro.ru

A.M. Orlov

Laboratory of Ecology of Lower Vertebrates, A.N. Severtsov Institute of Ecology and Evolution, Russian Academy of Sciences, Russia

A.M. Orlov

Chair of Ichthyology, Dagestan State University, Russia

A.M. Orlov

Chair of Ichthyology and Hydrobiology, Tomsk State University, Russia

A.M. Orlov

Laboratory of Marine Biology, Caspian Institute of Biological Resources, Dagestan Scientific Center of the Russian Academy of Sciences, Russia lower mesopelagic zone of 400-800 $\mathrm{m}$ depths and cold temperatures of $-0.5-1^{\circ} \mathrm{C}$. In the near-bottom layer catches of smooth lumpsucker were represented by fish with TL 5-45 cm (mean $28.1 \mathrm{~cm}$, dominant lengths 29-37 cm) while in water column its TL varied 4 to $41 \mathrm{~cm}$ with mean $17.9 \mathrm{~cm}$, most abundant were fish with TL 8-15 and $24-31 \mathrm{~cm}$; the difference is associated with specific life history aspects of the species considered. Recent increase of smooth lumpsucker biomass in the study area was observed with estimated value of $3000 \mathrm{t}$ in the northern Primorye.

Keywords: smooth lumpsucker Aptocyclus ventricosus, Sea of Japan, spatial and vertical distributions, water temperature, size composition, biomass

\section{Introduction}

Smooth lumpsucker Aptocyclus ventricosus (Pallas) (Cyclopteridae, Scorpaeniformes, Actinopterygii) is distributed widely in the North Pacific from coastal waters to high seas, from sea surface to deep-water layers, including seamounts (Hughes 1981, Mecklenburg et al. 2002). Its range in the Sea of Japan covers the entire area from Busan on the continental part and Wakasa Bay (central part of Honshu Island, Japan) in the south to the northern Tatar Strait in the north (Lindberg and Krasyukova 1987, Amaoka et al. 1995, Nakabo 2002). 
In many areas of its habitation, $A$. ventricosus is a common or abundant species (Fedorov and Parin 1998, Sheiko and Fedorov 2000, Chereshnev et al. 2000, Fedorov et al. 2003, Bailey 2011) playing a considerable role in fish communities (Il'inskii and Radchenko 1992). It is rather important in trophic chains, having been eaten by Steller's sea lions Eumetopias jubatus, fur seals and seals (Odobenidae, Otariidae, Phocidae), sperm whales Physeter macrocephalus, sea otters Enhydra lutris, bald eagles Haliaeetus leucocephalus, and Steller's sea eagles Haliaeetus pelagicus (Vinogradov 1950, Berzin 1959, Hart 1973, Kato 1982, Anthony et al. 1999, 2008, Utekhina et al. 2000, Watt et al. 2000, Reisewitz et al. 2006, Zeppelin and Ream 2006, McKenzie and Wynne 2008, Sinclair et al. 2008, Blokhin 2010). It is also occasionally found in stomachs of some predatory fish on the continental slope (Yang and Livingston 1988, Orlov 1997), for instance, Greenland halibut Reinhardtius hippoglossoides (Walbaum) and sablefish Anoplopoma fimbria (Pallas). On the other hand, smooth lumsucker consume predominantly coelenterates (Yoshida and Yamaguchi 1985, Arai 1988, Ates 1988). This species is also considered prospective for maintenance in public aquariums (Orlov et al. 2015).

It might be noted that smooth lumpsucker males die after completing a cycle of guarding their nests (Vinogradov 1950). They became an easy prey of marine birds and their dead bodies are involved into biogenic exchange increasing contents of organic matter in coastal waters. Thus smooth lumpsucker represents important link of trophic webs transporting organic matter from the lower trophic levels (gelatinous plankton) to highest ones (birds, marine mammals and humans).

Smooth lumpsucker during its life cycle inhabits various biotopes, including both pelagic and near-bottom environments, from sea surface and tidal areas to high sea and oceanic depths. These various biotopes are inhabited by the variety of different species co-occurring with smooth lumpsucker in catches. The data on species that are accompanied by smooth lumpsucker in catches are scarce and scattered in published literature. Meanwhile, such data are important for better understanding of the life cycle and the position of species considered in different communities.

Distribution of smooth lumpsucker was described in details for the Bering Sea (Yoshida and Yamaguchi 1985, Il'insky and Radchenko 1992) and Pacific waters of the northern Kuril Islands and southeastern Kamchatka (Orlov and Tokranov 2008). As for the Sea of Japan, some data on distribution and catch rates of smooth lumpsucker within in the Russian EEZ might be obtained from several recent publications (Shuntov and Bocharov 2004a, 2004b, 2014a, 2014b). Recently, the data on catches of the species under consideration in waters around Hokkaido were also published (Yoshida and Mihara 2015). However, above-mentioned publications are in Russian and Japanese respectively and thus are hardly accessible for readers worldwide.

Despite its rather high abundance, this species has no commercial importance in Russian fisheries and is taken only in trawls as by-catch (Fedorov and Parin 1998, Chereshnev et al. 2001, Novikov et al. 2002, Fedorov et al. 2003). However in Japan, $A$. ventricosus has some commercial value. In the 1960s, in waters off southern Hokkaido, its annual catch comprised from 2 to $40 \mathrm{t}$; however, market prices were low (Kyushin 1975). In recent years (2001-2005) annual catch in waters off Hokkaido varied between 210 and $587 \mathrm{t}$ with average catch of $328 \mathrm{t}$ (Yoshida and Mihara 2015). Nevertheless, the life history of smooth lumpsucker of the Sea of Japan is poorly understood. Published papers are dealing mostly with its taxonomy and zoogeography (Ueno 1970, Lindberg and Krasyukova 1987) or with reproductive biology and early ontogeny (Homma 1957, Kobayashi 1962, Kyushin 1975, Kim et al. 1987, Novikov et al. 2002, Sokolovsky et al. 2011, Zhukova et al. 2018).

The main objective of the current research is to analyze horizontal and vertical distributions of smooth lumpsucker within the Russian waters of the Sea of Japan depending on season and water temperature, to consider size and quantitative characteristics of the species and to evaluate dynamics of its biomass for better understanding of species ecology and some specific life history traits. 


\section{Material and methods}

Data used in this research came from 159 trawl surveys conducted in the northwestern Sea of Japan, 1978-2014 (Fig. 1). The total number of hauls was 16232 (including 2392 mid-water trawls), with smooth lumpsucker registered in 799 hauls. Between calendar seasons the data of the catch were distributed as follows: bottom trawl hauls - 45 in winter, 431 in spring, 85 in summer and 116 in autumn; mid-water trawl hauls - 39 in winter, 40 in spring, 14 in summer and 29 in autumn. Bottom trawl hauls were conducted within the depth range 2 to $940 \mathrm{~m}$, while mid-water trawls covered depths from the sea surface down to $750 \mathrm{~m}$.

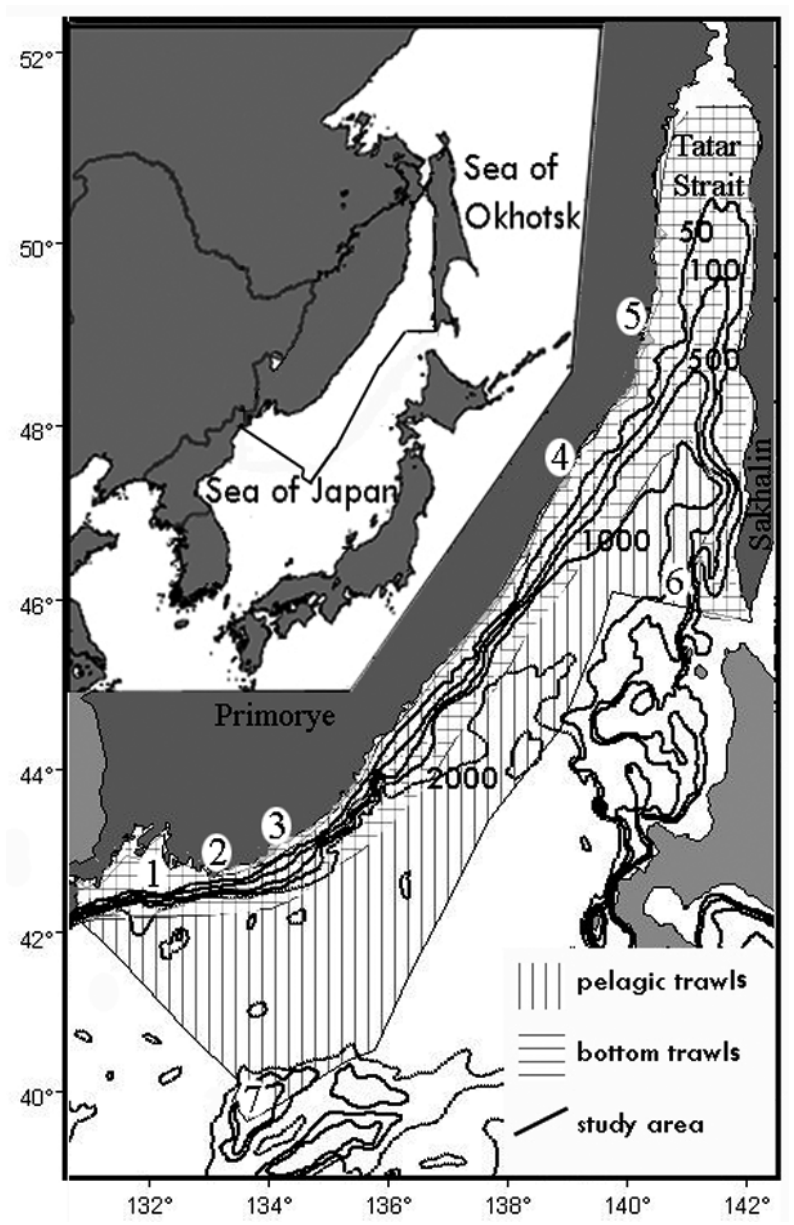

Figure 1. Russian EEZ of the Sea of Japan covered by research trawl surveys; 1 - Peter the Great Bay, 2 - Cape Povorotny, 3 Preobrazheniye Bay, 4 - Cape Zolotoy, 5 - Sovetskaya Gavan' Bay, 7 - Kita-Yamato Bank; 50, 100, 500, 1000, and 2000 isobaths.
During trawl surveys, various types of vessels and gears were used. Vessels were represented by trawlers, whose length varied 21.9 to $103.7 \mathrm{~m}$, width -6.0 to $16.0 \mathrm{~m}$, displacement tonnage -104 to 5720 $\mathrm{t}$, main engine power $-1 \times 110$ to $2 \times 2580 \mathrm{Kw}$. The main vessel used in recent years (RV "Bukhoro") is $103.7 \mathrm{~m}$ long and $8.8 \mathrm{~m}$ wide with displacement tonnage $549 \mathrm{t}$ and main engine power $1 \times 590 \mathrm{Kw}$.

Bottom trawls used during the surveys had vertical and horizontal openings 5-8 and 13-17 m respectively, those dimensions of mid-water trawls were 10-30 and 30-70 m. Mesh size in both types of gears varied 30 to $50 \mathrm{~mm}$, codend was equipped with a small-size mesh $(10 \mathrm{~mm})$ insert panel.

To standardize the survey data and to neutralize the impact of trawling speed, the type of vessel and the different trawl characteristics, all catches were recalculated to standard CPUE $\left(\mathrm{kg}\right.$ per $\left.\mathrm{km}^{2}\right)$ that represents area surveyed (S) multiplied by an average catch per hour (n). The data from mid-water trawl hauls were used for map charting in the pelagic layer only since mid-water trawls had relatively high vertical opening. For biomass estimations and the analysis of vertical distribution of smooth lumpsucker we used the data from bottom trawl hauls only.

Biomass of smooth lumpsucker was estimated based on results of bottom trawl surveys only (as most representative) with the use of square methods by formula:

$$
B=\frac{S \times n}{q \times k}, \text { where }
$$

$B$ - biomass (t), $S$-area surveyed $\left(\mathrm{m}^{2}\right), n$ - average catch per hour (kg per h), $q$ - mean area fished per hour ( $\mathrm{m}^{2}$ per $\left.\mathrm{h}\right), k$ - coefficient of catchability.

Value of $q$ was estimated by formula:

$$
q=v+h, \text { where }
$$

$v$ - trawling speed (m per h), $h$ - horizontal opening of trawl $(\mathrm{m})$ that was considered equal to 0.6 of the length of upper headline for each trawl. The total biomass was calculated as the sum of biomass estimated for each standard depth stratum (0-20, 21-50, 51-100, 101-200, 201-300, 301-400, 401-500, 501-700, and 701-1000 m), using catchability 


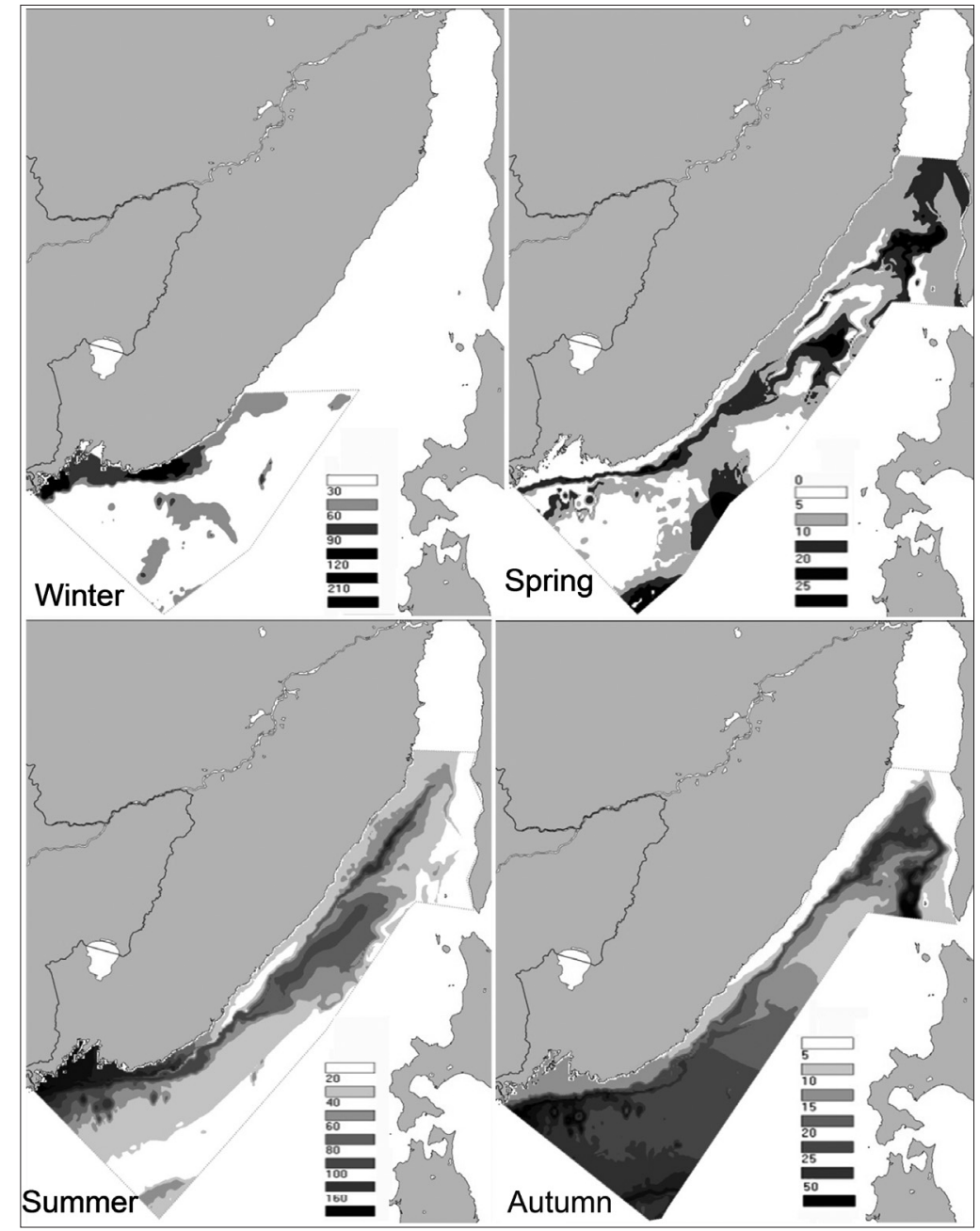

Figure 2. Spatial distribution ( $\mathrm{kg}$ per $\mathrm{km}^{2}$ ) of smooth lumpsucker (Aptocyclus ventricosus) pelagic trawl catches in the northwestern Sea of Japan, 1981-2012.

coefficient $(k)$ of 0.5 (Shuntov and Bocharov 2014a, 2014b).

Spatial distribution maps were drawn using Chartmaster 4.1 software (CVNIRO, Moscow, 2003-2008; @Polyakov A.V., Novocherkassk, 2003-2008).

Total length (TL, cm) was measured for 865 specimens (including 108 ind. from mid-water and 757 ind. from bottom trawl catches); body weight (BW, g) was determined in 180 fish. The fish body weight was estimated with water swallowed that is typical for some lumpsuckers of the family Cyclopteridae, e.g. smooth lumpsucker Aptocyclus ventricosus and Eumicrotremus soldatovi Popov (Orlov 1994, Orlov and Tokranov 2008).
Water temperature was measured using SBE 19plus SeaCAT Profiler CTD (Sea-Bird Scientific, USA) after most of bottom trawl station from the sea surface to the bottom in automatic mode. There were 572 measurements of water temperature in total with 365 measurements in spring, 94 in summer, 110 in autumn and 3 in winter. Bottom temperatures were used to characterize seasonal patterns of smooth lumpsucker distribution depending on water temperature.

The analysis of the composition of species co-occurring with smooth lumpsucker in catches was done based on the frequency of occurrence. During the trawl surveys the whole catch was analysed. It was sorted by species, then individuals were counted 


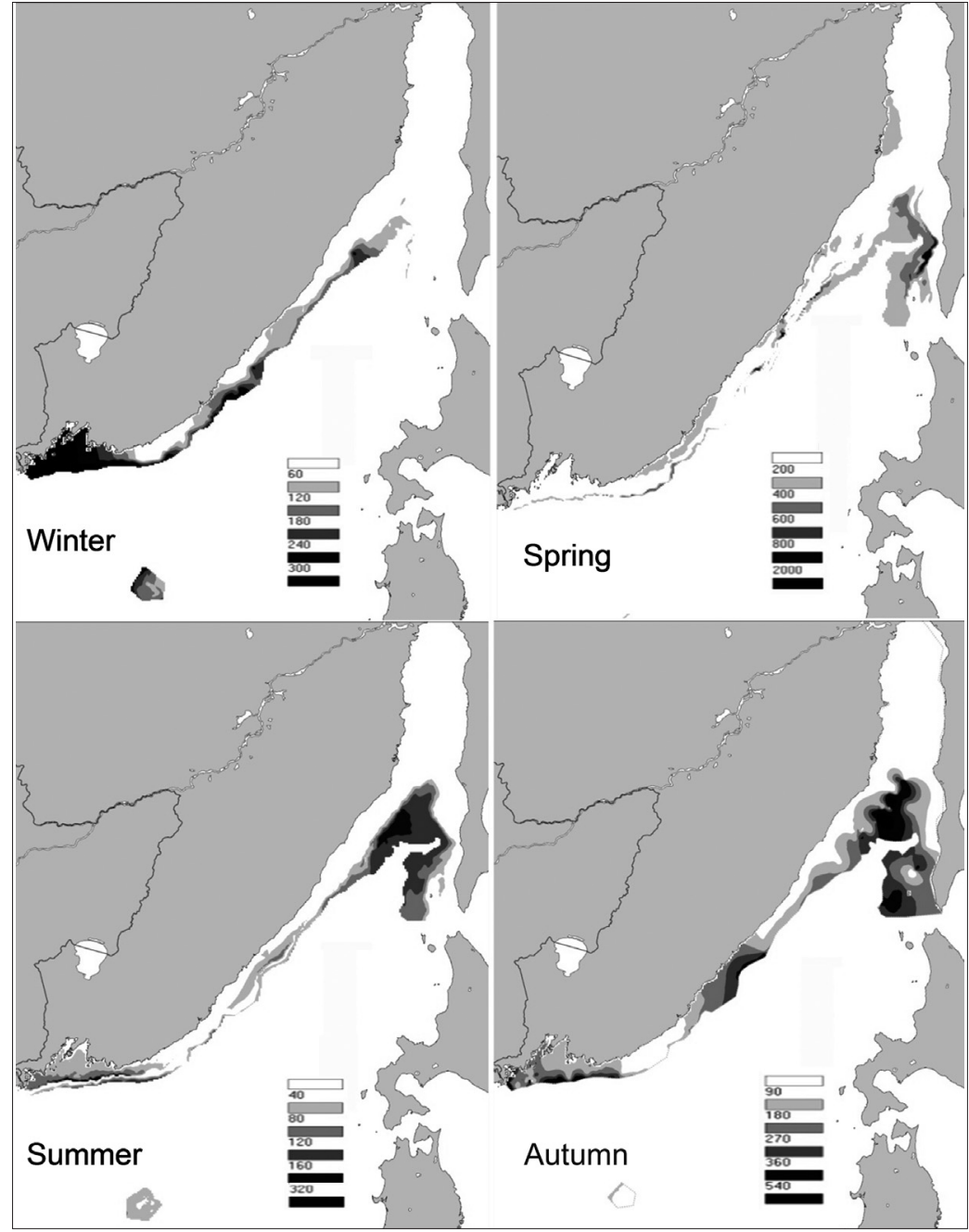

Figure 3. Spatial distribution $\left(\mathrm{kg}\right.$ per $\mathrm{km}^{2}$ ) of smooth lumpsucker (Aptocyclus ventricosus) bottom trawl catches in the northwestern Sea of Japan, 1978-2014.

and weighed. The frequency of occurrence (FO, \%) for each species was calculated as a percentage of trawls in which this species was recorded.

\section{Results}

\section{Spatial distribution}

The horizontal distribution of smooth lumpsucker based on the data from mid-water trawl hauls is shown for different seasons in Fig. 2, and it covered almost the entire Russian Exclusive Economic Zone (EEZ), with an exception of northern Tatar Strait. In the water column, during spring (March-May), density of smooth lumpsucker aggregations was rather low with maximum about $25 \mathrm{~kg}$ per $\mathrm{km}^{2}$. Such a density occurred in the southern part of Tatar Strait, off central Primorye and in the southern part of Russian EEZ along the border of Japanese waters. In summer (June-August), density of lumpsucker aggregations increased up to $160 \mathrm{~kg}$ per $\mathrm{km}^{2}$ with highest CPUE in the southern part of Russian EEZ, in the Peter the Great Bay. In autumn (September-November), density of aggregations again decreased with maximum CPUE values down to $50 \mathrm{~kg}$ per $\mathrm{km}^{2}$. Most dense schools were observed off the Peter the Great Bay, off the southwestern Sakhalin 




Figure 4. Bathymetric distributions of smooth lumpsucker (Aptocyclus ventricosus) catches in the northwestern Sea of Japan in different seasons (bars are means + standard errors), 1982-2014.

and in southeastern corner of Russian EEZ. In winter (December-February), smooth lumpsucker inhabited southern part of the Russian EEZ only with maximum concentrations up to $210 \mathrm{~kg}$ per $\mathrm{km}^{2}$. Such dense schools occurred in the western part of the Peter the Great Bay and in the southern Primorye from Cape Povorotny to Preobrazheniye Bay.

Spring horizontal distribution of lumpsucker catches from bottom trawls (Fig. 3) was very dense (up to $2000 \mathrm{~kg}$ per $\mathrm{km}^{2}$ ) but occurred off southwestern Sakhalin only. In summer, the area of occurrence in southern part of Tatar Strait considerably extended but density of aggregations decreased down to $320 \mathrm{~kg}$ per $\mathrm{km}^{2}$. In autumn period, density of schoolings slightly increased (up to $520 \mathrm{~kg}$ per $\mathrm{km}^{2}$ ) with maximum concentrations still occurred in the southern part of Tatar Strait and off the Peter the Great Bay. Winter concentrations of smooth lumpsucker near the bottom were similar in value to those in summer and occurred mostly in the Peter the Great Bay. In the southernmost part of the Russian EEZ, on the Kita-Yamato Bank, smooth lumpsucker was accounted in catches all year round. Less frequently this species occurred in catches in this area during winter and spring.

Both bottom and mid-water trawl hauls revealed similar seasonal patterns of spatial distribution of smooth lumpsucker within the Russian EEZ. In spring it is widely distributed in this area and forms dense concentrations in the southern part of Tatar Strait, off southwestern Sakhalin only. In summer and autumn periods both near the bottom and in water column, species considered concentrates mostly in the southern part of Tatar Strait and partly in the Peter the Great Bay. In winter time, it occurs predominantly in the southern part of the Russian EEZ with maximum concentrations in the southern Primorye and the Peter the Great Bay.

\section{Depth distribution}

The smooth lumpsucker in the Sea of Japan inhabited the entire depth range surveyed (0 to $940 \mathrm{~m}$ ) (Fig. 4). Off the Kita-Yamato Bank, capture depth of smooth lumpsucker varied from 490 to $740 \mathrm{~m}$ (mean 


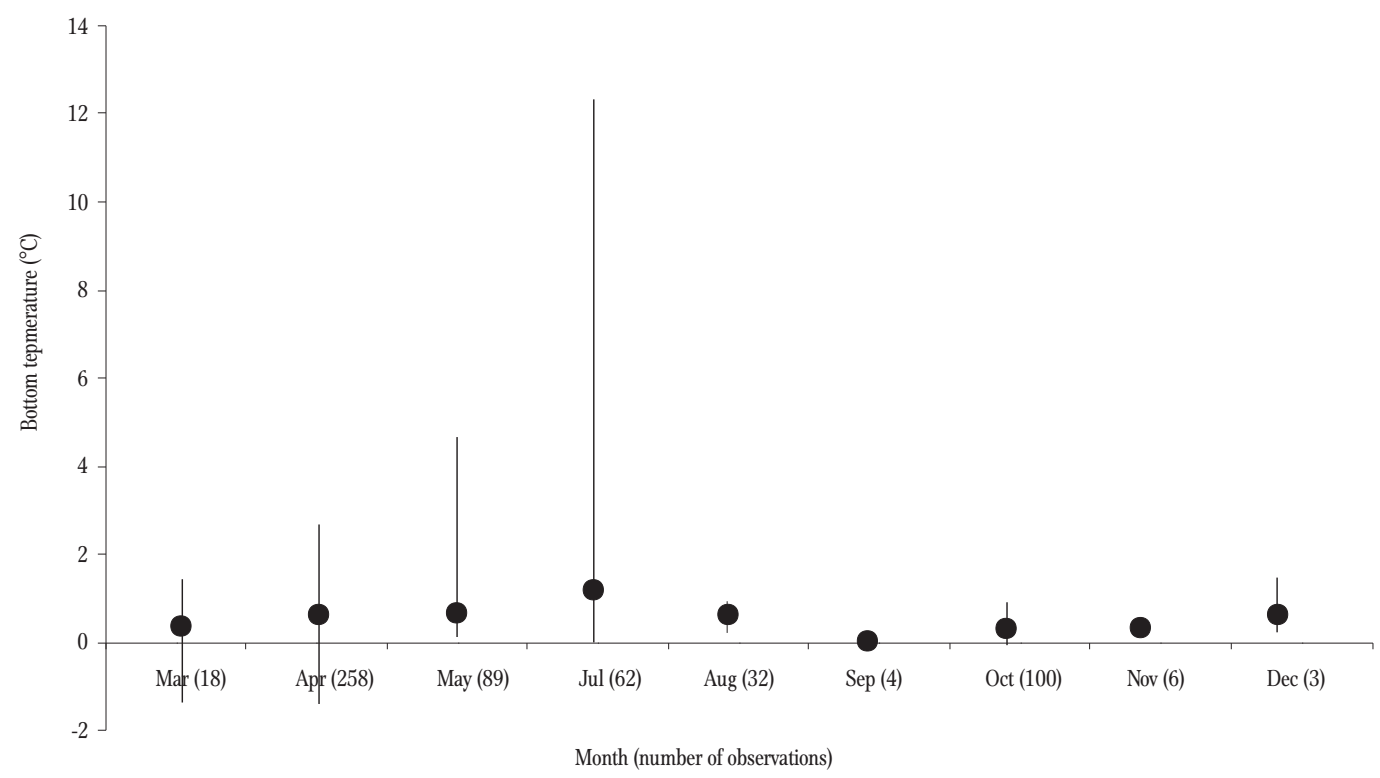

Figure 5. Monthly distributions of smooth lumpsucker (Aptocyclus ventricosus) in the northwestern Sea of Japan depending on the bottom temperature, 2004-2014 (dots are means, bars are variations).

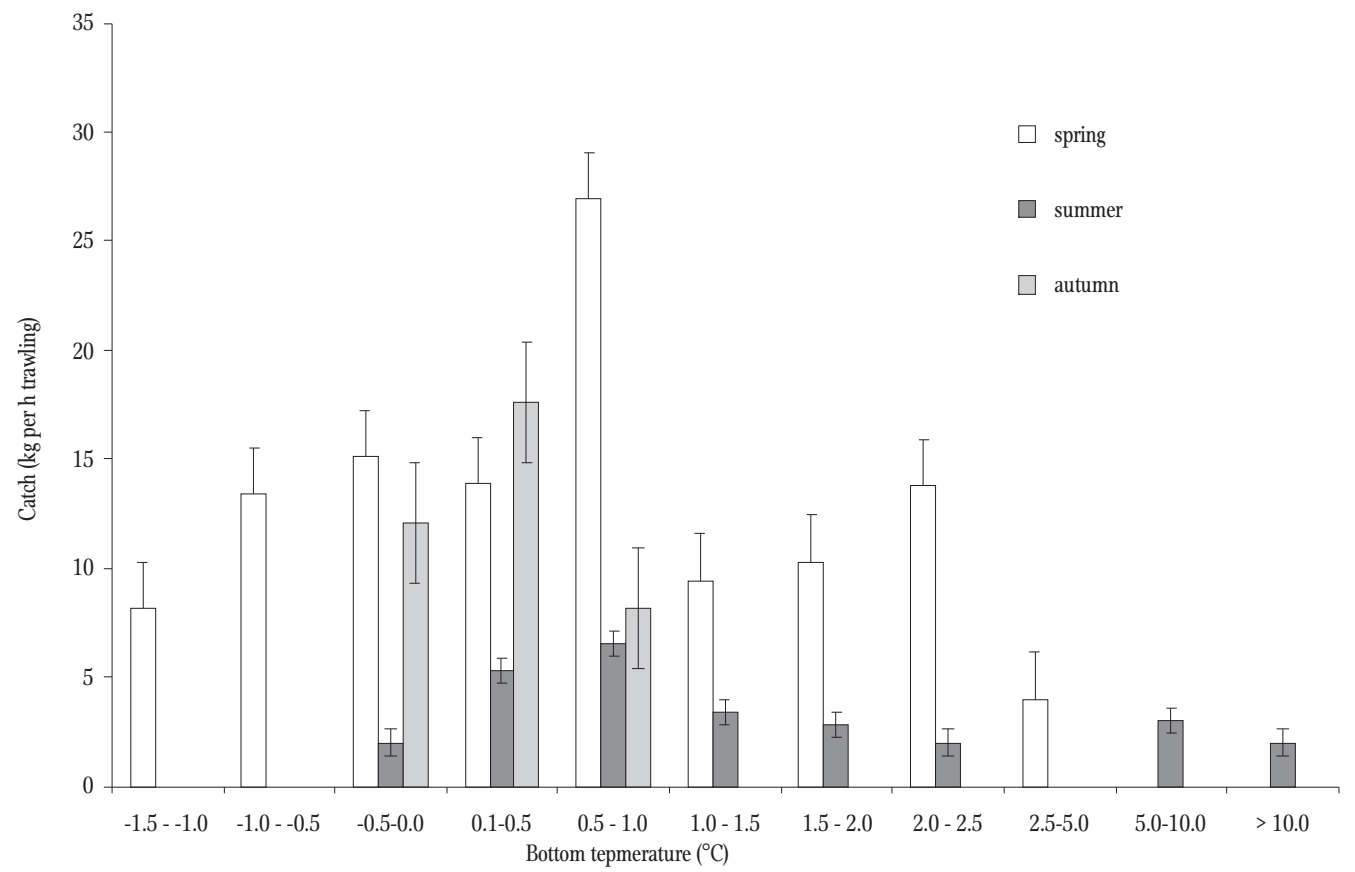

Figure 6. Distribution of smooth lumpsucker (Aptocyclus ventricosus) bottom catches in the northwestern Sea of Japan depending on water temperature in different seasons, 2004-2014 (bars are means + standard errors).

$536 \mathrm{~m})$. However, during the most part of the year it was observed between 400 and $800 \mathrm{~m}$. As a rule, smooth lumpsucker prefers several noncontiguous depths layers, where its catches are largest. In summer and autumn, these depths are 400-500 and 700-800 m, in spring 5-20, 500-600, and 700-800 $\mathrm{m}$. In winter, its catches are not high at any depths.

\section{Temperature conditions}

Smooth lumpsucker occupies waters with wide temperature range from $-1.1^{\circ} \mathrm{C}$ to $12.2^{\circ} \mathrm{C}$ that depends on the season of study. Maximum value of mean bottom temperature was registered in July $\left(1.16^{\circ} \mathrm{C}\right)$ while minimum one $\left(-1.1^{\circ} \mathrm{C}\right)$ was observed in March 

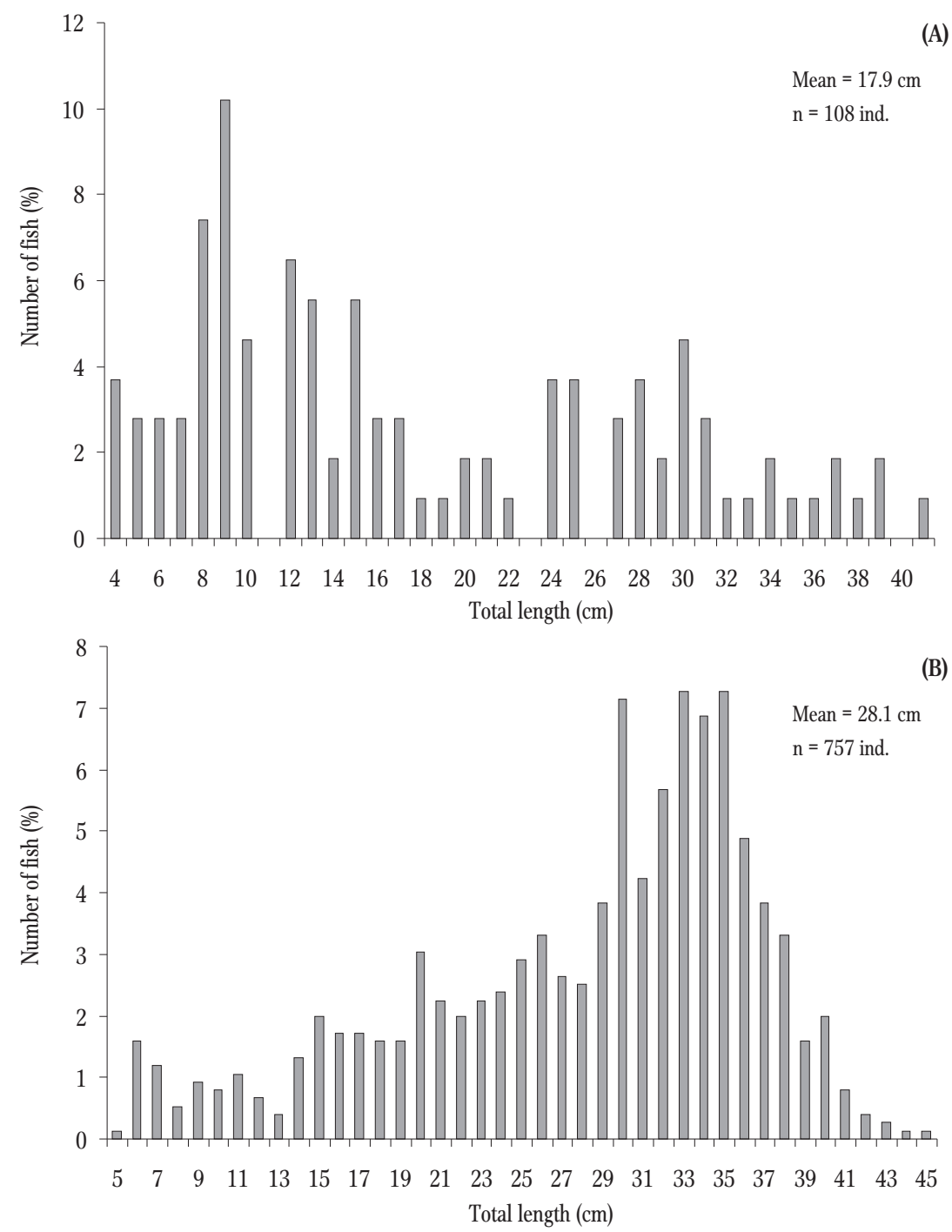

Figure 7. Size composition of smooth lumpsucker (Aptocyclus ventricosus) in the northwestern Sea of Japan in mid-water (A), 1984-1997 and bottom (B), 2004-2014 trawl catches.

and April (Fig. 5). In March and April, smooth lumpsucker occurred at negative temperatures. Widest range of bottom temperatures was observed in July. In this period smooth lumpsucker was distributed within broad depth range from 25-30 m with temperatures more than $10^{\circ} \mathrm{C}$ to over $600 \mathrm{~m}$ where temperatures were about $0^{\circ} \mathrm{C}$.

Smooth lumpsucker exhibits some seasonal changes in temperature-depending distribution (Fig. 6). In spring, it was observed from 1.5 to $5.0^{\circ} \mathrm{C}$ with highest catches (9.4-26.9 ind. $\mathrm{h}^{-1}$ ) within temperature range $-1.0-1.0^{\circ} \mathrm{C}$. In summer, it occupied warmer temperatures within the range from -0.5 to over $10.0^{\circ} \mathrm{C}$ with highest catches (3.4-6.5 ind. $\mathrm{h}^{-1}$ ) from 0.1 to $1.5^{\circ} \mathrm{C}$. Autumn distribution was characterized by very narrow range $\left(-0.5-1.0^{\circ} \mathrm{C}\right)$ with catches varied 8.2-17.6 ind. $\mathrm{h}^{-1}$. However, during the most part of the year maximum catches of smooth lumpsucker were observed at a temperature range from -0.5 to $1.0^{\circ} \mathrm{C}$.

\section{Size composition}

Total length (TL) of smooth lumpsucker in catches varied from 4 to $45 \mathrm{~cm}$ (Fig. 7). Catches of mid-water trawl were dominated by two modal size classes 
(8-15 cm, 45\% and $24-31 \mathrm{~cm}, 25 \%)$ with mean total length of $17.9 \mathrm{~cm}$. Mean TL in bottom trawl catches made up to $28.1 \mathrm{~cm}$ while specimens with TL 29 to $37 \mathrm{~cm}$ were most abundant (47\%). Relation between length and body weight of smooth lumpsucker in the Sea of Japan was described by the following equation:

$$
W=0.14 \times T L^{2.7306}
$$

where $\mathrm{W}$ is body weight in grams and TL is total length in centimeters (Fig. 8).

\section{Co-occurring species}

Total species composition of bottom trawls with catches of smooth lumpsucker was indicative for the entire bathymetric range preferred by this species. The most frequently co-occurring species were scale-eye plaice Acanthopsetta nadeshnyi Schmidt with frequency of occurrence $70 \%$, darkfin sculpin Malacocottus zonurus Bean - 59\%, and Commander squid Berryteuthis magister - 51\%. The following species also co-occurred frequently with smooth lumpsucker: northern shrimp Pandalus borealis 49\%, Korean flounder Glyptocephalus stelleri (Schmidt) - 47\%, and Tanner crab Chionoecetes opilio - $40 \%$.

In mid-water trawls smooth lumpsucker was more frequently caught together with walleye pollock Theragra chalcogramma Pallas - 82\%, Japanese sardine Sardinops melanostictus (Jenyns) - 80\%, Japanese flying squid Todarodes pacificus - 55\%, arabesque greenling Pleurogrammus azonus Jordan \& Metz-43\%, pink salmon Oncorhynchus gorbuscha (Walbaum) - 38\%, Pacific herring Clupea pallasii Val. - 27\%, and Commander squid - 20\%. Frequency of occurrence of other species in mid-water trawl catches was less than $20 \%$.

\section{Demography}

Annual estimations of smooth lumpsucker biomass for different areas of the northwestern Sea of Japan varied considerably. In the Peter the Great Bay, an

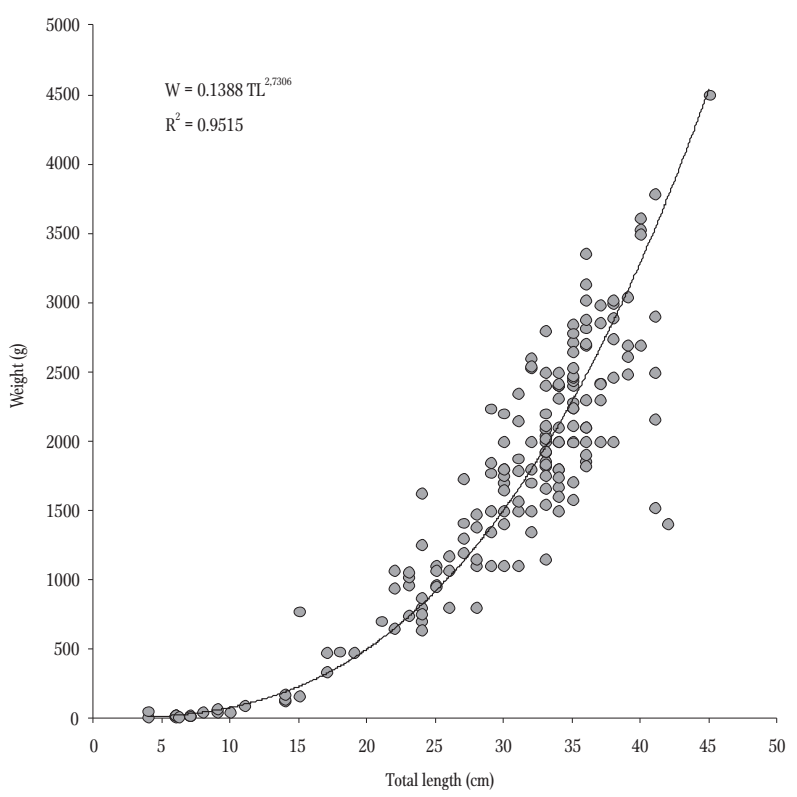

Figure 8. Relationship between total length and body weight of smooth lumpsucker (Aptocyclus ventricosus) in the northwestern Sea of Japan, 1982-2014.

increasing trend was observed, with maximum biomass values in the period 2009 to 2010 , followed by biomass decline (Table 1). Off the continental part of the Tatar Strait, maximum values of smooth lumpsucker biomass were observed in 2011 to 2012, followed by subsequent sharp decline. The species occurred in the northern Primorye regularly but its biomass reached maximum values only recently (2013-2014).

\section{Discussion}

\section{Spatial distribution}

Spatial distribution of smooth lumpsucker in the Sea of Japan prior to our research was poorly understood. Its distribution is determined, to a great extent, by seasonal changes in water temperature that, in its turn, impact physiological condition of fish, i.e. relating to spawning, feeding, and wintering that are associated with inshore and offshore migrations.

As our data showed (Figs. 2 and 3), in winter and spring periods, smooth lumpsucker is distributed mostly in coastal waters that most likely associated 
Table 1

Biomass ( $\mathrm{t}$ ) of smooth lumpsucker (Aptocyclus ventricosus) in various areas of the northwestern Sea of Japan (number of hauls is shown in brackets). Symbol «-» means that there was no research survey in particular year, 0.0 means that smooth lumpsucker lacked in catches, PGB = Peter the Great Bay $\left(11\right.$ thousands $\left.\mathrm{km}^{2}\right), \mathrm{NP}=$ northern Primorye $\left(33\right.$ thousands $\left.\mathrm{km}^{2}\right)$, TS $=$ continental part of the Tatar Strait (30 thousands $\mathrm{km}^{2}$ )

\begin{tabular}{|c|c|c|c|c|c|c|c|c|c|c|c|c|c|c|}
\hline \multirow[b]{2}{*}{ Area } & \multicolumn{14}{|l|}{ Year } \\
\hline & 2001 & 2002 & 2003 & 2004 & 2005 & 2006 & 2007 & 2008 & 2009 & 2010 & 2011 & 2012 & 2013 & 2014 \\
\hline \multirow{3}{*}{ PGB } & 0.0 & 0.0 & 21.1 & 0.0 & 0.0 & 0.0 & 0.0 & 51.2 & 160.9 & 200.7 & 39.4 & 0.0 & 87.2 & 44.0 \\
\hline & (128) & (124) & (122) & (131) & (148) & (140) & (141) & (124) & (304) & (145) & (101) & (115) & (121) & (123) \\
\hline & - & 191.6 & - & 162.7 & 147.2 & - & 152.3 & - & 487.8 & 382.5 & 801.9 & 909.1 & 3058.7 & 2114.2 \\
\hline $\mathrm{NP}$ & & (143) & & (165) & (154) & & (180) & & (178) & (161) & (172) & (166) & (165) & (167) \\
\hline \multirow{3}{*}{ TS } & - & - & - & - & - & - & - & - & 0.0 & 0.0 & 552.9 & 688.6 & 0.0 & 130.9 \\
\hline & & & & & & & & & (136) & (156) & (146) & (143) & (114) & (139) \\
\hline & 0.0 & 191.6 & 21.1 & 162.7 & 147.2 & 0.0 & 152.3 & 51.2 & 648.7 & 583.2 & 1394.2 & 1597.7 & 3145.9 & 2289.1 \\
\hline Total & (128) & (267) & (122) & (296) & (302) & (140) & (321) & (124) & (618) & (462) & (419) & (424) & (400) & (429) \\
\hline
\end{tabular}

with inshore spawning. Spawning season of smooth lumpsucker, due to its lengthiness in time, are quite similar for various parts of species' range: February to May in the Pacific waters of the northern Kuril Islands and Kamchatka (Orlov and Tokranov 2008), December to June in the western Bering Sea (Il'insky and Radchenko 1992), February to May in the northwestern Sea of Japan and Hokkaido (Kyushin 1975, Novikov et al. 2002). Seasonal catch dynamics may provide additional information about duration of spawning period. Thus, maximum catches in the $\mathrm{Pa}$ cific waters off the northern Kuril Islands and southeastern Kamchatka (Orlov and Tokranov 2008) occur in February-April, in Korean waters of the Sea of Japan and off Hokkaido (Lee et al. 2010, Yoshida and Mihara 2015) in February-March.

Published data on spatial distribution of smooth lumpsucker in other part of its range is rather scarce (Yoshida and Yamaguchi 1985, Orlov and Tokranov 2008, Romain et al. 2012). However, seasonal patterns of spatial distribution of the species in various areas are quite similar. In winter and spring its main concentrations occur in coastal waters that is associated with spawning period, while in summer and autumn it is widely distributed throughout its range, mostly inhabiting areas distant from coasts. During the feeding period, smooth lumpsucker inhabits mostly pelagic environment and this is probably main reason why bottom trawl catches notably decrease in summer and autumn.

\section{Depth distribution}

The species ecology is characterized by a wide range of depth distribution. This species inhabits both pelagic and near-bottom water layers from the sea surface down to $1700 \mathrm{~m}$ (Allen and Smith 1988, Novikov et al. 2002, Fedorov et al. 2003). It should be noted that in the Sea of Japan, this species prefers deepest depths as compared to other more northern areas. In the western Bering Sea, smooth lumpsucker is most frequently observed at depths 100 to $200 \mathrm{~m}$ (Il'insky and Radchenko 1992), in the central Bering Sea (Donut Hole) - between 50 and $260 \mathrm{~m}$ (Glubokov and Popov 2004), in the southeastern Bering Sea $-<250 \mathrm{~m}$ (Sinclair and Stabeno 2002), in the eastern Bering Sea and northeastern Pacific - at depths 50 to $100 \mathrm{~m}$ (Allen and Smith 1988), in the Pacific off the northern Kuril Islands and Kamchatka - at 200-400 m (Orlov and Tokranov 2008), in the Sea of Okhotsk - between 400 and $600 \mathrm{~m}$ (Shuntov 1965). During the eastern Bering Sea continental slope bottom trawl survey, this species occurred much deeper - 216 to $1172 \mathrm{~m}$ with mean depth 712 m (Hoff 2016). 


\section{Temperature conditions}

In the Pacific waters off the northern Kuril Islands and southwestern Kamchatka the species prefers rather narrow range of water temperatures from 0.6 to $2.5^{\circ} \mathrm{C}$ (Orlov and Tokranov 2008) that is associated with its preference of deep waters where temperatures do not vary significantly. In coastal waters, temperatures in areas of smooth lumpsucker habitation vary seasonally and at a greater scale. Thus in waters of southern Hokkaido near Shikabe, temperature at the sea bottom at depths about $10 \mathrm{~m}$ is about $3-5^{\circ} \mathrm{C}$ in February, about $4-6^{\circ} \mathrm{C}$ in April (smooth lumpsucker spawning period is between early February and early April), and gradually rises to $6-7^{\circ} \mathrm{C}$ in early May (the hatching season in nature is from early April to early May) (Kyushin 1975). The maximum known temperature for Primorye waters at which smooth lumpsucker was recorded previously was $8.4^{\circ} \mathrm{C}$ (Orlov and Tokranov 2008). We recorded some specimens in July at temperatures over $10^{\circ} \mathrm{C}$ that lie within known summer temperature range for this species: it was previously recorded at temperature $13^{\circ} \mathrm{C}$ in waters off southeastern Kamchatka (Vinogradov 1950) and at $14-15^{\circ} \mathrm{C}$ off Hokkaido (Kyushin 1975).

\section{Size composition}

Larger sizes of smooth lumpsucker in bottom trawls in shelf waters, as compared to fish collected in mid-water trawls, were also observed in other areas of the species' range (Il'insky and Radchenko 1992, Glubokov and Popov 2004). In general, size compositions of smooth lumpsucker in various parts of its distribution range have a similar pattern: its length somewhat increases southward. Thus, mean lengths were $26.2 \mathrm{~cm}$ in pelagic layer above the shelf zone of the western Bering Sea (Il'insky and Radchenko 1992) and $28.9 \mathrm{~cm}$ in the Pacific off the northern Kuril Islands and southeastern Kamchatka (Orlov and Tokranov 2008). Demersal gill net catches off southern Hokkaido during smooth lumpsucker spawning period consist of females with mean total length $35.1 \mathrm{~cm}$ (range 31 to $39 \mathrm{~cm}$ ) and males with mean total length $30.3 \mathrm{~cm}$ (range 26 to $36 \mathrm{~cm}$ ) (Kyushin 1975).

Low number of small-sized fish in our bottom trawls might be explained by the fact that juvenile smooth lumpsuckers inhabit mostly pelagic waters. At the same time, size composition of smooth lumpsucker in mid-water catches resembles that from the Aleutian Basin of the Bering Sea (Yoshida and Yamaguchi 1985, Glubokov and Popov 2004), where fishes of two size classes (9-16 cm and 17-36 $\mathrm{cm})$ were also most abundant. Larger specimens greater than $17 \mathrm{~cm}$ long have well developed gonads that characterize their condition as sexually mature. This observation allowed authors to suggest that specimens attained $T L$ at least $17 \mathrm{~cm}$ will migrate to coastal waters in the following year for spawning. We assume that this conclusion might be extrapolated to size composition of our catches as well.

Relationships between smooth lumpsucker total length and body weight for more northern areas look somewhat differently (Il'insky and Radchenko 1992, Orlov and Tokranov 2008) that might be associated with different amount in fish weight of swallowed water that cannot be tested statistically. Small-sized smooth lumpsuckers from the Sea of Japan seem to have lesser body weight as compared with fish of the same length from other areas. However, linear growth is associated with increase in body weight that in large smooth lumpsuckers from the study area seems to be higher as compared with fish from Pacific waters off Kuril Islands and Kamchatka and quite similar to fish from the Bering Sea (Il'insky and Radchenko 1992, Orlov and Tokranov 2008).

\section{Co-occurring species}

Smooth lumpsucker is widely distributed in the North Pacific from subtropical and temperate to boreal and subarctic waters. This results in different composition of co-occurring species in various parts of species' range. Data on composition of species co-occurring with smooth lumpsucker are mostly available from mid-water surveys. Pelagic catches 
conducted in surface waters off Hokkaido and Kuril Islands were mainly composed by Japanese sardine, Japanese anchovy Engraulis japonicus Temminck \& Schlegel, Pacific saury Cololabis saira (Brevoort), Pacific salmon Oncorhynchus spp., and various squids (Ueno et al. 1990). In water column of the eastern Bering Sea, species most frequently caught with smooth lumpsucker were walleye pollock, Pacific herring, Pacific salmon, capelin Mallotus villosus (Müller), eulachon Thaleichthys pacificus (Richardson), and various squids (Yoshida and Yamaguchi 1985, Brodeur et al. 1999). During the eastern Bering Sea summer salmon survey (Morita et al. 2007) most frequently caught together with smooth lumpsucker were Pacific salmon, walleye pollock, and Atka mackerel Pleurogrammus monopterygius (Pallas).

In the Gulf of Alaska, mid-water trawl catches (apart from smooth lumpsucker) most frequently contained walleye pollock, eulachon, capelin, Pacific herring, arrowtooth flounder Atheresthes stomias (Jordan \& Gilbert), flathead sole Hippoglossoides elassodon Jordan \& Gilbert, Pacific hake Merluccius productus (Ayres), northern smoothtongue Leuroglossus schmidti Rass, Pacific viperfish Chauliodus macouni Bean, and various squids (Csepp et al. 2011, Romain et al. 2012).

Data on species composition of bottom trawl catches containing smooth lumpsucker are very limited. During recent eastern Bering Sea bottom trawl survey (Hoff 2016), frequency of occurrence of smooth lumpsucker in catches was $30.2 \%$ with most frequently occurred Aleutian skate Bathyraja aleutica (Gilbert) - 77.8\%, Kamchatka flounder Atheresthes evermanni Jordan \& Starks - 77.8\%, Greenland halibut - 67.2\%, giant grenadier Albatrossia pectoralis (Gilbert) - 64.0\%, shortspine thornyhead Sebastolobus alascanus Bean - 63.5\%, arrowtooth flounder - 52.9\%, Commander squid $52.4 \%$ and other species less than 50\%.

Composition of bottom trawl catches in the Gulf of Alaska containing species considered were notably different with most frequently caught slender sole Lyopsetta exilis (Jordan \& Gilbert), sculpins of the genus Triglops, sturgeon poacher Podothecus accipenserinus (Tilesius), spinyhead sculpin
Dasycottus setiger Bean, shortfin eelpout Lycodes brevipes Bean, and capelin (Mueter and Norcross 2002). Co-occurring species in catches with smooth lumpsucker in the northern Sea of Japan differ considerably from those in Pacific waters off the northern Kuril Islands, Eastern Bering Sea and the Gulf of Alaska due to differences in species composition of communities of above-mentioned areas that are located in different zoogeographic provinces.

As for mid-water trawls, some species are common for the northwestern Sea of Japan and other areas, for instance walleye pollock, Pacific herring, Pacific salmon, and squids in the Bering Sea and Gulf of Alaska (Yoshida and Yamaguchi 1985, Brodeur et al. 1999, Morita et al. 2007, Csepp et al. 2011, Romain et al. 2012) and Pacific salmon, Japanese sardine, Japanese anchovy, and squids off Hokkaido and Kuril Islands (Ueno et al. 1990).

The analysis of published and our own data shows that smooth lumpsucker occupies specific ecological niche consuming predominantly coelenterates (Yoshida and Yamaguchi 1985, Arai 1988, Ates 1988) and therefore does not represent potential predator or food competitor for the majority of fish inhabiting the same biotopes. The species cannot be considered as common prey for predatory fish and squid due to its specific lifestyle and very rare occurrence in predator stomach records (Yang and Livingston 1988, Orlov 1997).

\section{Biomass and demography}

It should be noted that in our study area frequency of occurrence (FO) of smooth lumpsucker is considerably lower as compared to the Bering Sea. Thus, in our catches its $\mathrm{FO}$ was $5.1 \%$ in midwater trawls and $4.9 \%$ in bottom trawls while in the midwater trawl catches in the western Bering Sea its FO made up 8.5-39.0\% (Brodeur et al.1999, Chodakov et al. 2004), 50.0\% in the southeastern Bering Sea (Sinclair and Stabeno 2002), and 76.9\% - in the central Bering Sea (Donut Hole) (Glubokov and Popov 2004).

The data on the absolute values of smooth lumpsucker estimated biomass in various parts of species' 
range in rather limited. Il'inskii and Radchenko (1992) estimated biomass of this species in the western Bering Sea as 14,250-73,190 metric tons that is at least 4.5-23 times more than in the area of our research. In the eastern Bering Sea it was recently estimated as $378 \mathrm{t}$ (Hoff 2016) that is 6-8 times less as compared to recent estimations of biomass of this species within Russian EEZ in the Sea of Japan. There are the data on relative biomass $\left(\mathrm{kg}_{\text {per }} \mathrm{km}^{2}\right)$ of the species under consideration within the Russian EEZ in the Sea of Japan, Sea of Okhotsk, western Bering Sea, and Pacific Ocean off Kamchatka and Kuril Islands (Shuntov and Bocharov 2003, 2004a, 2004b, 2005, 2006, 2012a, 2012b, 2012c, 2014a, 2014b, 2014c). However, these data are hardly comparable with our estimations of absolute values of smooth lumpsucker biomass.

It is known that abundance of smooth lumpsucker might undergo dramatic changes, from unanticipated arrivals of large number of fish to coastal waters to their complete disappearance (Doak et al. 2008, Hoff 2016, Conner et al. 2017). The possible reasons for such extreme changes in smooth lumpsucker abundance are still poorly understood. The considerable recent increase of smooth lumpsucker biomass in the Sea of Japan, in our opinion, is associated with the rise of abundance of the species within its entire range. Thus, in adjacent Sea of Okhotsk mean density of smooth lumpsucker in research surveys during 1984-2009 increased from 1.2 to $11.6 \mathrm{t}$ per $\mathrm{km}^{2}$ (i.e. 10 times); in some areas (TINRO Basin) its density recently reached $53.5 \mathrm{t}$ per $\mathrm{km}^{2}$ (Shuntov and Bocharov 2014c). According to data (available at http:/www.afsc.noaa.gov/RACE/groundfish/survy_data/ data.htm) came from research surveys of AFSC (Alaska Fisheries Science Center), catch per unit effort (CPUE, kg per ha) increased from $0.22-0.29$ in 1983-1986 to 0.46-0.79 in 2004-2006 off the Aleutian Islands and from 0.41 in 1984-1987 to 0.81 in 2007 in the Gulf of Alaska. Data of AFSC observers (available at http://www.afsc.noaa.gov/FMA/fma_database.htm) also testify to increase of smooth lumpsucker abundance in Alaskan waters. Thus, in 1994-1995 mean catch of species under consideration made up 17.4-25.9 kg (0.0017 to $0.0025 \%$ of total catch) while in $2001-2003$ respective values increased to $39.2-89.9 \mathrm{~kg}$ and $0.0082-0.0282 \%$.
Notable increase in occurrence and catch rates of smooth lumpsucker in early 2000s, as compared to 1990s, were noted in Pacific waters of the northern Kuril Islands and southeastern Kamchatka (Orlov and Tokranov 2008). The rise of the total catch of this species in 2000-2006 was registered also in waters of Hokkaido (Yoshida and Mihara 2015).

The factors determining recent changes of smooth lumpsucker abundance in the North Pacific in the whole and in the Sea of Japan in particular are largerly unknown. However, it is possible to suggest that they may relate to the changes in abundance of recruitment that are associated with rather short life span of the species under consideration. There are no studies of age and growth of smooth lumpsucker. However, maximum age of its relative, lumpfish Cyclopterus lumpus L., does not exceed 10 years (Davenport 1985). Since spawning of smooth lumpsucker, similarly to that of lumpfish, occurs in shallow coastal waters, survival of its eggs and larvae largerly depends on many factors, such as storms, temperature conditions, currents, predation by invertebrates, fishes and marine birds (Davenport 1985).

\section{Conclusion}

Smooth lumpsucker in the Russian EEZ has wide distribution both horizontally and vertically. It is less abundant in small bays and in the northern Tatar Strait (north to $\left.50^{\circ} \mathrm{N}\right)$. Despite wide bathymetric (0 to $940 \mathrm{~m})$ and temperature $\left(-1.1\right.$ to $\left.+12.2^{\circ} \mathrm{C}\right)$ ranges, this species prefers depths $400-800 \mathrm{~m}$ and temperatures $0-1{ }^{\circ} \mathrm{C}$. Size compositions of fish caught in water column and near the bottom differ considerably. In the water column its mean length was $17.9 \mathrm{~cm}$ while near the bottom it was $28.1 \mathrm{~cm}$ that is related to species life history. The estimated biomass of smooth lumpsucker observed in the northern Primorye in 2003 was about $3000 \mathrm{t}$ that is about $2 \%$ of the total fish biomass in the area.

Acknowledgements. Authors are grateful to all colleagues who took part in research surveys which data were used in preparation of this paper. We also thank 
AFSC (Alaska Fisheries Science Center, Seattle, USA) for open-access to data obtained during research surveys and observer program. Special thanks to Dr. Alexander Yarzhombek (VNIRO), who helped with translation of some Japanese publications, and to Dr. Evgeny Sabourenkov (SFP Regional Coordinator, Hobart, Australia) for improvement of English. We also thank an anonymous reviewers for valuable comments and suggestions. Contribution of A.M. Orlov to this research was partially supported by the Russian Fund of Basic Research (grant No. 16-04-00456).

Author contributions. S.F.S. provided the initial data, did the analysis, prepared the figures, and edited the manuscript; A.M.O. did the analysis, wrote and edited the manuscript.

\section{References}

Allen M.J., Smith G.B. 1988 - Atlas and zoogeography of connom fishes in the Bering Sea and northeastern Pacific - US Dept. Commer., NOAA Tech. Rept. NMFS 66: 1-158.

Amaoka K., Nakaya K., Yabe M. 1995 - The fishes of northern Japan - Kita-nihon Kaiyo Center Co., Sapporo, 390 p. (in Japanese).

Anthony R.G., Miles A.K., Estes J.A., Isaacs F.B. 1999 - Productivity, diets, and environmental contaminants in nesting bald eagles from the Aleutian Archipelago - Environ. Toxicol. Chem. 18: 2054-2062.

Anthony R.G., Estes J.A., Ricca M.A., Miles A.K., Forsman E.D. 2008 - Bald eagles and sea otters in the Aleutian Archipelago: indirect effects of trophic cascades - Ecology 89: 2725-2735.

Arai M.L. 1988 - Interactions of fish and pelagic coelenterates - Can. J. Zool. 66: 1913-1927.

Ates R.M.L. 1988 - Medusivorous fishes, a review - Zool. Mededelingen 62: 29-42.

Bailey K.M. 2011 - An empty Donut Hole: the great collapse of a North American fishery - Ecology and Society 16: 2 (online).URL: http://www.ecologyandsociety.org/vol16/ iss $2 / \operatorname{art} 28 /$.

Berzin A.A. 1959 - On the feeding of sperm whales (Physeter catodon) in the Bering Sea - Izv. TINRO 47: 161-165 (in Russian).

Blokhin I.A. 2010 - Diet identification from analysis of excrements and traits of feeding by northern fur seals (Callorhinus ursinus) in the Bering Island in 2000-2007 Issledovaniya Vodnykh Biologicheskikh Resursov
Kamchatki I Severo-Zapadnoi Chasti Tikhogo Okeana 19: 116-126 (in Russian).

Brodeur R.D., Wilson M.T., Walters G.E., Melnikov I.V. 1999 - Forage fishes in the Bering Sea: distribution, species associations, and biomass trends - In: Dynamics of the Bering Sea (Eds) T.R. Loughlin, K. Ohtani, Univ.of Alaska Sea Grant, Fairbanks, USA: 509-580.

Chereshnev I.A., Volobuev V.V., Khovanskii I.E., Shestakov A.V. 2000 - Coastal fishes from the northern part of the Sea of Okhotsk - Dal'nauka, Vladivostok, 197 p (in Russian).

Chodakov A.V., Norvillo G.V., Buslov A.V. 2004 - Some results of bottom and midwater trawl survey for walleye pollock (Theragra chalcogramma) in the western Bering Sea in October-November 2003 aboard the ship "Bagration" - Document submitted for IX Bering Sea Pollock Conference, Kushiro, Japan, 2004 - Federal Agency for Fisheries of the Russian Federation, Moscow, $15 \mathrm{p}$.

Conner J., Stevenson D.E., Lauth R.R. 2017 - Results of the 2014 eastern Bering Sea continental shelf bottom trawl survey of groundfish and invertebrate resources - US Dept. Commer., NOAA Tech. Memo. NMFS-AFSC 350: $1-154$.

Csepp D.J., Vollenweider J.J., Sigler M.F. 2011 - Seasonal abundance and distribution of pelagic and demersal fishes in southeastern Alaska - Fish. Res. 108: 307-320.

Davenport J. 1985 - Synopsis of biological data on the lumpsucker, Cyclopterus lumpus (Linnaeus, 1758) - FAO Fish. Synopsis 147: 1-31.

Doak D.F., Estes J.A., Halpern B.S., Jacob U., Lindberg D.R., Lavvorn J., Monson D.H., Tinker M.T., Williams T.M., Wootton J.T., Carroll I., Emmerson M., Micheli F., Novak M. 2008 - Understanding and predicting ecological dynamics: are major surprises inevitable? - Ecology 89: 952-961.

Fedorov V.V., Parin N.V. 1998 - Pelagic and benthopelagic fishes from Pacific waters of Russia - VNIRO, Moscow, 154 p. (in Russian).

Fedorov V.V., Chereshnev I.A., Nazarkin M.V., Shestakov A.V., Volobuev V.V. 2003 - Catalog of marine and freshwater fishes of the northern Sea of Okhotsk - Dal'nauka, Vladivostok, 204 p. (in Russian).

Glubokov A.I., Popov S.B. 2004 - Results of echointegration and trawl surveys in the Donut Hole during November 2003 aboard the ship "Pioner Nikolaeva" - Document submitted for IX Bering Sea Pollock Conference, Kushiro, Japan, 2004, Federal Agency for Fisheries of the Russian Federation, Moscow: 9 p.

Hart J.L. 1973 - Pacific fishes of Canada - Bull. Fish. Res. Board. Can. 180: 1-740.

Hoff G.R. 2016 - Results of the 2016 Eastern Bering Sea upper continental slope survey of groundfish and 
invertebrate resources - NOAA Tech. Memo. NMFS-AFSC 339: 1-288.

Homma Y. 1957 - Notes on a smooth lump-sucker, Aptocyclus ventricosus (Pallas), during its breeding season - Collecting and Breeding 19: 235-236 (in Japanese).

Hughes S.E. 1981 - Initial U.S. exploitation of nine Gulf of Alaska seamounts and their associated fish and shellfish resources - Mar. Fish. Rev. 43: 26-33.

Il'insky E.N., Radchenko V. I. 1992 - Distribution and migrations of smooth lumpsucker in the Bering Sea - Biol. Morya 3-4: 19-25 (in Russian).

Kato H. 1982 - Food habits of largha seal pups in the pack ice area - Sci. Rep. Whales Res. Inst. 34: 123-136.

Kim Y.U., Park Y.S., Myoung J.G. 1987 - Development of eggs, larvae and juveniles of smooth lumpsucker, Aptocyclus ventricosus (Pallas) - Bull. Korean Fish. Soc. 20: $157-165$.

Kobayashi K. 1962 - Larvae of the smooth lumpsucker, Aptocyclus ventricosus (Pallas), with discussion on revision of the taxonomy of the species - Bull. Fac. Fish. Hokkaido Univ. 8: 153-164.

Kyushin K. 1975 - The embryonic and larval development, growth, survival and changes in body form, and the effect of temperature on these characteristics of the smooth lumpsucker, Aptocyclus ventricosus (Pallas) - Bull. Fac. Fish. Hokkaido Univ. 26: 49-72.

Lee H.W., Hong B.K., Sohn M.H., Chun Y.Y., Lee D.W., Choi Y.M., Hwang K.S. 2010 - Seasonal variation in species composition of fish collected by trammel net around Dokdo, East Sea of Korea - Kor. J. Fish. Aquat. Sci. 43: 693-704.

Lindberg G.U., Krasyukova Z.V. 1987 - Fishes of the Sea of Japan and adjacent parts of Okhotsk and Yellow Seas, Pt. 5, Nauka, Leningrad, 526 p. (in Russian).

Litzow M.A., Mueter F.J. 2014 - Assessing the ecological importance of climate regime shifts: an approach from the North Pacific - Progr. Oceanogr. 120: 110-119.

McKenzie J., Wynne K.M. 2008 - Spatial and temporal variation in the diet of Steller sea lions in the Kodiak Archipelago, 1999 to 2005 - Mar. Ecol. Prog. Ser. 360: 265-283.

Mecklenburg C.W., Mecklenburg T.A., Thorsteinson L.K. 2002 - Fishes of Alaska - Am. Fish. Soc., Bethesda, MD, USA, $1116 \mathrm{p}$.

Morita K., Sato S., Kagaya M., Katayama Y., Goda Y., Chiba T., Makino K. 2007 - The 2007 summer Japanese salmon research cruise of the R/V Hokko-maru, NPAFC Doc. 1044 - NPAFC Headquarters, Vancouver, BC, Canada, 8 p. (available at http://www.npafc.org).

Mueter F.J., Norcross B.L. 2002 - Spatial and temporal patterns in the demersal fish community on the shelf and upper slope regions of the Gulf of Alaska - Fish. Bull. 100: 559-581.
Nakabo T. 2002 - Fishes of Japan with pictorial keys to the species, English edition -Tokai University Press, Tokyo, $1800 \mathrm{p}$.

Novikov N.P., Sokolovsky A.S., Sokolovskaya T.G., Yakovlev Y.M. 2002 - The fishes of Prymorye - Dal'rybvtuz, Vladivostok, 552 p. (in Russian).

Orlov A.M. 1994 - Some characteristics of distribution and biological status of Eumicrotremus soldatovi (Cyclopteridae) in the northeastern part of the Sea of Okhotsk in spring - J. Ichthyol. 34: 122-127.

Orlov A.M. 1997 - The qualitative characteristic of feeding of the sablefish Anoploroma fimbria with notes on its occurrence in the Pacific waters of the northern Kuril Islands and southeastern Kamchatka - J. Ichthyol. 37: 3-40.

Orlov A.M. 2005 - Bottom trawl-caught fishes and some features of their vertical distribution in the Pacific waters off the north Kuril Islands and south-east Kamchatka, 1993-1999 - Aqua, J. Ichthyol. Aquat. Biol. 9: 139-160.

Orlov A.M., Tokranov A.M. 2008 - Specific features of distribution, some features of biology, and the dynamics of catches of smooth lumpsucker Artocyclus ventricosus (Cyclopteridae) in waters of the Pacific Ocean off the Kuril Islands and Kamchatka - J. Ichthyol. 48: 81-95.

Orlov A.M., Stroganov A.N., Telegin A.V. 2015 - Perspective representatives of boreal-arctic ichthyofauna for expositions in oceanariums - Uspekhi Sovremennogo Estestvoznaniya 9: 317-330 (in Russian).

Reisewitz S.E., Estes J.A., Simenstad C.A. 2006 - Indirect food web interactions: sea otters and kelp forest fishes in the Aleutian Archipelago - Oecologia 146: 623-631.

Romain S., Dorn M., Wespestad V. 2012 - Results of cooperative research acoustic survey of walleye pollock (Theragra chalcogramma) in the western Gulf of Alaska from September 2007 to September 2011 - US Dept. Commer., NOAA Tech. Memo. NMFS-AFSC 238: 1-35.

Sheiko B.A, Fedorov V.V. 2000 - Class CephalaspidomorrhiLampreys. Class Chondrichthyes - Cartilaginous Fish. Class Holocephali - Chimaeras. Class Osteichthyes Bony Fish - In: Catalog of vertebrate animals of Kamchatka and adjacent areas (Eds) R.S. Moiseev, A.M. Tokranov, Kamchatskii Pechatnyi Dvor, Petropavlovsk-Kamchatsky: 7-69 (in Russian).

Shuntov V.P. 1965 - Vertical zonality in distribution of fishes in upper bathyal of the Sea of Okhotsk - Zool. Zhurnal 44: 1678-1689 (in Russian).

Shuntov V.P., Bocharov L.N. 2003 - Atlas of quantitative distribution of nekton species in the Okhotsk Sea, Maps, Vol. 1 - National Fisheries Resources, Moscow, 1038 p. (in Russian).

Shuntov V.P., Bocharov L.N. 2004a - Atlas of nekton species quantitative distribution in the northwestern Sea of Japan, Maps, Vol. 2 - National Fisheries Resources, Moscow, 986 p. (in Russian). 
Shuntov V.P., Bocharov L.N. 2004b - Nekton of the northwestern Sea of Japan. Tables of abundance, biomass and proportions of species - TINRO-Center, Vladivostok, 225 p. (in Russian).

Shuntov V.P., Bocharov L.N. 2005 - Atlas of nekton species quantitative distribution in the north-western part of the Pacific Ocean, Maps, Vol. 3 - National Fisheries Resources, Moscow, 1080 p. (in Russian).

Shuntov V.P., Bocharov L.N. 2006 - Atlas of nekton species quantitative distribution in the western part of the Bering Sea, Maps, Vol. 4 - National Fisheries Resources, Moscow, 1071 p. (in Russian).

Shuntov V.P., Bocharov L.N. 2012a - Pelagic macrofauna of the western part of the Bering Sea: occurrence, abundance and biomass, 1982-2009 - TINRO-Center, Vladivostok, 479 p. (in Russian).

Shuntov V.P., Bocharov L.N. 2012b - Pelagic macrofauna of the northwestern Pacific: occurrence, abundance and biomass, 1979-2009 - TINRO-Center, Vladivostok, 616 p. (in Russian).

Shuntov V.P., Bocharov L.N. 2012c - Pelagic macrofauna of the Okhotsk Sea: occurrence, abundance and biomass, 1984-2009 - TINRO-Center, Vladivostok, 800 p. (in Russian).

Shuntov V.P., Bocharov L.N. 2014a - Macrofauna of the Peter the Great Bay benthal: tables of occurrence, abundance and biomass, 1978-2009 - TINRO-Center, Vladivostok, 307 p. (in Russian).

Shuntov V.P., Bocharov L.N. 2014b - Macrofauna of the northwestern Sea of Japan benthal: tables of occurrence, abundance and biomass, 1978-2010 - TINRO-Center, Vladivostok, 748 p. (in Russian).

Shuntov V.P., Bocharov L.N. 2014c - Macrofauna of the Sea of Okhotsk pelagial: tables of occurrence, abundance and biomass, 1984-2009 - TINRO-Center, Vladivostok, 800 p. (in Russian).

Sinclair E.H., Stabeno P.J. 2002 - Mesopelagic nekton and associated physics of the southeastern Bering Sea Deep-Sea Res. II 49: 6127-6145.

Sinclair E.H., Vlietstra L.S., Johnson D.S., Zeppelin T.K., Byrd G.V., Springer A.M., Ream R.R., Hunt G. 2008 - Patterns in prey use among fur seals and seabirds in Pribilof Islands - Deep-Sea Res. II. 55: 1897-1918.

Sokolovsky A.C., Sokolovskaya T.G., Yakovlev Y.M. 2011 Fishes of the Peter the Great Bay - Dal'nauka, Vladivostok, 431 p. (in Russian).

Ueno T. 1970 - Fauna Japonica. Cyclopteridae (Pisces) - Academic Press of Japan, Tokyo, 233 p.

Ueno Y., Shimizu I., Shershenev A.P. 1990 - Surface water type and distribution of juvenile fishes and cephalopods in Pacific coast waters of Hokkaido and the Kuril Islands in summer, 1989 - Bull. Nat. Res. Inst. Far. Seas Fish. 27: 57-70.

Utekhina I., Potapov E., McGrady M.J. 2000 - Diet of Steller's sea eagle in the Sea of Okhotsk - First Symposium on Steller's and White-tailed Sea Eagles in East Asia -Wild Bird Society of Japan, Tokyo: 71-82.

Vinogradov K.A. 1950 - On the biology of smooth lumpsucker in waters off Kamchatka - Priroda 3: 69-70 (in Russian).

Yang M-S., Livingston P.A. 1988 - Food habits and daily ration of Greenland halibut, Reinhardtius hippoglossoides, in the eastern Bering Sea - Fish. Bull. 86: 675-690.

Watt J., Siniff D. B., Estes J.A. 2000 - Inter-decadal patterns of population and dietary change in sea otters at Amchitka Island, Alaska - Oecologia 124: 289-298.

Yoshida H. 1994 - Food and feeding habit of pelagic walleye pollock in the central Bering Sea in summer, 1976-1980 - Sci. Rep. Hokkaido Fish. Exp. Stn. 45: 1-35.

Yoshida H., Yamaguchi H. 1985 - Distribution and feeding habits of the pelagic smooth lumpsucker, Aptocyclus ventricosus (Pallas), in the Aleutian basin - Bull. Fac. Fish. Hokkaido Univ. 36: 200-209.

Yoshida H., Mihara Y. 2015 - Catches of smooth lumpsucker, Aptocyclus ventricosus (Pallas) in Hokkaido - Sci. Rep. Hokkaido Fish. Res. Inst. 88: 59-68 (in Japanese).

Zeppelin T.K., Ream R.R. 2006 - Foraging habitats based on the diet of female northern fur seals (Callorhinus ursinus) on the Pribilof Islands, Alaska - J. Zool. 270: 565-576.

Zhukova K.A., Maznikova O.A., Orlov A.M. 2018 - Gonadal maturation of the female smooth lumpsucker (Aptocyclus ventricosus) - Fish. Bull. 116: 53-160. 